\title{
STUDENT SATISFACTION WITH ASYNCHRONOUS LEARNING
}

Charles Dziuban, Patsy Moskal and Jay Brophy

Research Initiative for Teaching Effectiveness

University of Central Florida

Peter Shea

University at Albany

\begin{abstract}
The authors discuss elements that potentially impact student satisfaction with asynchronous learning: the media culture, digital, personal and mobile technologies, student learning preferences, pedagogy, complexities of measurement, and the digital generation. They describe a pilot study to identify the underlying dimensions of student satisfaction with online learning and present examples of techniques for engaging students in classes that respond to their uses of technology.
\end{abstract}

\section{KEYWORDS}

Student Satisfaction, Media Culture, Digital, Personal and Mobile Technologies, Student Learning Preferences, Pedagogy, Complexities of Measurement, Digital Generation

\section{INTRODUCTION}

Student satisfaction with asynchronous learning (ALN) is a complex blend of elements that mediates students' perceptions about their educational experiences. Recent work suggests that student evaluation of asynchronous classes is not bound entirely by satisfaction and dissatisfaction, but rather, lies on a continuum that extends from satisfaction to ambivalence, where very few students are genuinely dissatisfied with their online learning experiences [1]. Apparently, satisfaction results from the interaction of demographic profiles, generational membership, and some affiliation to a loosely defined learning style construct. The underlying question becomes: are the constructs by which students evaluate their classes constant or variable? That is, when students are dissatisfied with their online learning experience, is it because they are on the opposite side of the same dimensions that produced satisfied respondents, or are they dissatisfied for completely different reasons?

\section{SATISFACTION IN THE MEDIA CULTURE AND A DIGITAL AGE}

\section{A. The Media}

A variety of authors have argued that technology and new media have a profound impact on individual, cultural, and social development [2, 3, 4]. Kellner, for example, suggests that contemporary media culture in this country is the primary mechanism for socialization of our young people and the major incubator for change [5]. He contends that the images, patterns, sequences, and sounds presented to the American public sculpt our day-to-day lives; define our political, social, and ethical values; define right from wrong; and provide the basic foundation for our information society. Certainly, the media culture has migrated to the web where sites such as Digg and Technorati scour the Internet, producing an algorithmic collection 
of news. Sites such as YouTube make images from around the world instantly accessible, while others allow anyone to contribute to blogs and wikis on sites such as Wikipedia.

These developments have not gone unnoticed. Wikipedia, for example, has generated significant interest from a wide range of authors $[6,7,8]$. Lanier cites Wikipedia as the prime example of the new online collectivism that centers influence in a bottleneck [9]. He argues that, presently, there is a frantic race to become the meta-site that develops the highest level of aggregation, subsuming and marginalizing the contributions of all other sites. He describes this as the "Hive Mind" that reveals what people with the most time and determination communicate. Friedman, however, cites this phenomenon as the new, worldwide information democracy that equalizes the opportunities for an individual to effectively compete with the conglomerate [10]. Doctrow declares that "Wikipedia isn't great because it's like the Britannica. The Britannica is great because it's authoritative, edited, expensive, and monolithic. Wikipedia is great at being free, brawling, universal, and instantaneous” [11]. Certainly, these technologies play a large part in framing student satisfaction with online learning on college campuses.

\section{B. Digital, Personal, and Mobile}

The past decade has seen the emergence of asynchronous learning networks in higher education and the parallel development of equally important personal technologies. In the digital information world, students' personal communication and social networking primarily center on cell phones, iPods, MP3s, personal computers, text messaging, and recently, video blogging. Social networking sites such as Friendster, MySpace, and Facebook allow global personal profiling and communication. Also, students have ready access to computing with instant information available through the Internet and responsive resources such as Google and Ask.com. The majority of today's students use the Internet for research far more often than the library [12]. These findings produce suppositions such as Library 2.0 that ask whether or not libraries in their present form continue to be relevant [13].

A tour across almost any campus reveals exercise equipment in recreation rooms equipped with cable television, and a media center in the student union that offers news, information, games, and entertainment. Colorful images abound in dining areas with students involved in electronic activities of every imaginable variety. Residence halls are filled with electronic devices that host marathon gaming tournaments with virtual groups from around the world. Our tour reveals a population of Net Generation students who have never known a world without PCs, the Internet, digitally recorded music, and mass communication [14]. Outwardly, students are social, collaborative, and interactive. The technologies they utilize are virtual, digital, and personal; therefore, they expect immediate access and response [15, 16, 17]. These developments in technology, news, information, and media can influence the satisfaction students express with their online courses.

\section{WHO ARE TODAY'S STUDENTS?}

\section{A. What Are They Like?}

Students on today's campuses are a subset of the millennial generation presenting substantial challenges to educators, who were trained in a command and control educational culture where "knowledge was power" and information was sequestered in libraries and in the offices of professors [18]. Students of the digital age, however, prefer to work in teams and take a community approach to problem solving and creativity. They grew up in relative economic security and their sense of entitlement emboldens their approach to higher education. The media attributes them with superior intellectual capacity and a higher motivation for achievement than any generation that preceded them. The Net generation is confident, sophisticated, articulate, and possess a strong sense of personal agency. These young people describe 
themselves as special, entitled, and empowered with an ability to achieve, succeed, and accomplish great things in their personal lives and in society $[19,20]$. Many believe that they have developed a strong sense of community and will make the world a better place because it provided them with so many advantages.

\section{B. How Do They Learn?}

Considering learning preference and technology skills, digital culture students are compelling in their multitasking with the apparent ability to change context and medium in a smooth and efficient manner, growing impatient with learning situations where information presents itself in a controlled linear process [21]. Some suggest that this generation prefers graphics to text and approaches learning as play rather than work [22]. The gaming approach allows them to use a trial-and-error strategy, effectively iterating to the solution [23]. Many of today's students process information quickly with an enhanced ability for pattern recognition and integrating multiple information components into constructs and visual images. A variety of authors argue that many in this generation view technology as a friend rather than a challenge. Their learning preferences give them a clear advantage in the digital sound bite age [24, 25, 26].

\section{What is the Downside?}

There are disadvantages in their approach to learning however, evidenced by some studies that describe their reliance on the instantaneous nature of digital information access as a surface intellectual functioning that inhibits their ability to delve deeply into a problem-solving situation [27]. This inability can result in a lack of sustained determination to finish a task and function at higher cognitive levels. Some find these students difficult to teach because they have been accustomed to a hyper-rich media environment. These students will shun any learning situation that does not involve their preferred modality and will communicate a lack of satisfaction [28].

Recent work by Twenge reinforces this lesser optimistic picture of the digital culture students. She sees this generation as matter-of-fact and self-focused-thus her designation of "Generation Me" (a term devised from prior attempts to label this "Net" or "Millennial" generation that coincides with the Microsoft operating system: Windows Millennium Edition, or ME) [29]. As a group, she sees them as imbued with an artificial sense of self-esteem spawned from many years of a curriculum that over inflated their self-concepts and instilled them with unrealistic expectations. She characterizes these digital natives by their belief in life determination by lottery, where good things will just happen and everyone deserves to be an "American Idol."

\section{Complexities of Satisfaction}

The cacophony of conflicting views about the generation of students on our college campuses underscores the reason why assessing satisfaction with asynchronous learning may be a complex undertaking. Is this the brightest, most motivated, and empowered generation in history or is this group of young people disinterested, disdainful, and cynical? Are today's university students the most tech savvy and information fluent generation in history, who navigate information and technology literacy, critical thinking, their social spaces, and the media culture seamlessly, or do they operate at a superficial level, failing to analyze, synthesize, and evaluate? Is this group of young people the most civic-minded and service-oriented in history or are they politically marginalized and even more cynical than Generation X? Understanding these social, economic, political, and collaborative dynamics is key to discovering student motivation in learning online, and thus identifying the underpinnings of satisfaction. 


\section{STUDENT SATISFACTION WITH ASYNCHRONOUS LEARNING}

\section{A. Foundational Studies}

Early work on measuring student evaluation of instruction provides further insights about the evolvement of student satisfaction with the online environment. For instance, some studies define three higher order dimensions for students expressing their satisfaction with classes: presentation, facilitation, and regulation [30]. A more complex nine-component model defines the satisfaction domain in terms of learning value, instructor enthusiasm, organization, interaction, rapport, coverage, assessment, assignments, and difficulty [31]. Other investigators demonstrate that students will show a high probability of assigning an excellent overall rating to an instructor (satisfaction) if, in their view, he or she facilitates their learning, effectively communicates ideas and information, organizes the course effectively, assesses student progress accurately, shows interest in students' learning, and demonstrates respect for his or her students [32]. Instructors who score high on those dimensions have the majority of their students expressing high levels of satisfaction with their learning environment independent of the course mode: face-to-face, fullyonline, blended, technology-enhanced, or interactive television.

\section{B. Satisfaction with ALN}

Recent research about online courses shows that students express satisfaction and experience success when they are involved in cohort, team-based learning experiences and have extensive access to faculty feedback and interaction [33]. Studies of satisfaction dimensionality with the online environment identify four underlying factors: student faculty interaction, active learning, time on task, and cooperation among students [34]. Interestingly, these elements closely correspond to those identified by Chickering, Erhmann and Kuh-emphasizing the principle that engaged students are satisfied students [35, 36]. When compared to their on-campus peers, online students tend to be more satisfied with student services and online learning appears to increase instructor efficiency with no decrease in student satisfaction [37, 38]. Effective instructional design components and facilitation of effective discourse tend to be precursors of student satisfaction as do models that that build a strong sense of learning community embedded in the social presence construct [39, 40,41]. This supports the argument that satisfaction derives from students valuing interaction and the opportunities that enable them to communicate actively [42]. Introverted students appreciate having time to think problems through carefully with time to reflect and be heard. Extroverted students value the additional opportunities to interact with the outside world, experiencing perspectives that would never be available to them in the face-to-face setting [43]. Apparently, however, logistic elements such as a well-defined course structure are also increasing satisfaction [44, 45]. These studies confirm our supposition that measures of student satisfaction with asynchronous courses are mediated by many elements that reflect student, faculty, and course characteristics. Moreover, these elements and several others cannot be considered independently because context is probably as important as the individual elements.

\section{A PILOT STUDY OF STUDENT SATISFACTION: PRELIMINARY FINDINGS}

A cooperative study between the University of Central Florida and the University at Albany funded by the Alfred P. Sloan Foundation will attempt to identify underlying student satisfaction dimensions with asynchronous learning. After a literature review and several student focus groups, survey instruments will be administered to a sample of students involved in online learning. A similar study that focuses on the reasons that faculty members choose to teach in the asynchronous environment, also funded by the Alfred P. Sloan Foundation, is underway at the University at Albany and the New Jersey Institute of Technology. The two studies intend to provide cross-validated data from faculty members and students about their 
reasons for persisting in online teaching and learning.

Early results from student focus groups and pilot survey items indicate that the majority of students who are involved in asynchronous courses prefer that modality over other formats and register repeatedly for online sections. This multiple registration process negates any adverse effects of students dropping courses because of the online modality. Most responses indicate that students enroll in fully online courses before they migrate to blended sections. Students choose the format that they believe will provide the most learning. Curiously, a high percentage of respondents designate the face-to-face mode (possibly explaining the desirability of the blended format). Universally, their notion of convenience appears to be the primary motivational factor for enrolling in asynchronous courses, with students indicating that not having to come to campus plays a significant role in their choice of formats. Convenience, however, requires a careful analysis to identify specific elements of this "catch all” term. Some preliminary reasons for high satisfaction levels show that their initial fear of online learning is unfounded and they use the word "enjoy" in their evaluation comments. Those who feel inhibited in face to-face-sections feel more comfortable communicating with their instructors and peers. Students believe that instructors' expectations are more clearly specified in online courses than in face-to-face sections, and indicate that their time management skills improve with experience. Although few in number, dissatisfied students prefer the face-to-face mode. Ambivalent students express skepticism about learning, feeling that class quality depends primarily on the instructor's teaching prowess.

These preliminary results will provide the basis for a further and more detailed study of general concepts such as flexibility, improved time management, engagement, responsiveness, ambivalence, skepticism, and what motivates students to prefer various course modalities.

\section{CONCLUSION: JAY BROPHY'S ENGAGEMENT STRATEGIES}

\section{A. Cell Phones}

On the first day of class I ask my students to hold up their cell phones. In a flash there are 470 cell phones waving in the air. When I ask them what they should do with them, they respond: "TURN THEM OFF." Instead of the "iron boot" control method, I tell them that I frequently forget to turn off my cell phone. Many times I take the call and weave it into the class discussion. My students are amazed at my response, and I find that fewer phones ring.

\section{B. A Ten-Minute Investment of Class Time}

About the third week of class, we have "cell phone" day. If enough cell phones ring during the first five minutes of class, I give the students 10-bonus points. The points impact minimally because there are 1,000 points in the course. Students arrange to have someone outside of class call them at precisely 3:30 p.m., the time class begins. We have videotaped the event and it is a cacophonous symphony. By 3:35 p.m. it is all over and we then discuss social networking and the role of support groups in their lives. It fits in nicely with discussions about stress and health. Rather than consider cells as a negative experience, we celebrate something that the students really love. It is great fun and well worth the small amount of class time.

\section{Movies and Music in Psychology}

At the beginning of the term in my introductory psychology course, I set up discussion groups in WebCT so that students can record their favorite movies and music. I used to have trouble getting students to log 
on and explore the site. Now, over $90 \% \log$ in within 24 hours. We port this information into an Excel spreadsheet, sort it, and make a top 100 list for the music and a top 50 list for the films. I purchase the DVDs and put the music on my iPod. I learn the lyrics to the top fifty songs and play cuts of the songs to introduce ideas for the class. Frequently, my students know all the lyrics and lines from the songs and films, so it is easy to connect course content to what is already well learned. Students respond positively to the idea that I am interested in what they like and am willing to learn about it.

\section{Coalescing Student Interests to Improve Engagement}

A casual observation reveals that Net Generation students immerse themselves in pursuits involving digital media that are becoming increasingly portable. A recent New York Times article featured the Digg website developers and their response to continuing interest in video blogging vs. text-based versions [46]. These new digital devices and their updates reveal their popularity with college-age students, who spend increasingly more money on personal technologies.

These personal devices are far more engaging than academic applications of technology. If one compared a typical course management system to Facebook, YouTube, or the computer game, Grand Theft Auto, the outcome for student engagement would be obvious. Therefore, we need to develop instructional strategies with that same compelling power to captivate in the asynchronous learning environment. The best way to gain that insight is to learn what students are doing with their free time. Successful companies spend great sums to engage their customers. Shouldn't the academy do the same if it wants real student engagement and satisfaction?

\section{ABOUT THE AUTHORS}

Chuck Dziuban is director of the Research Initiative for Teaching Effectiveness (RITE) at the University of Central Florida where he has been a faculty member for the past 33 years. RITE's charge is to gauge the impact of UCF's distributed learning initiative on students, faculty and the institution. In addition, Chuck Dziuban and Patsy Moskal assist faculty members with their research on improving university teaching. Dr. Dziuban specializes in applied multivariate analysis and psychometrics. His work on psychometric adequacy earned him a citation in the SAS manual and was the basis for a factor analysis strategy used in the SPSS statistical package. He is founding director of the Faculty Center for Teaching and Learning at UCF and serves as the university liaison to the Tangelo Park urban reform project sponsored by Orlando hotelier, Harris Rosen. Chuck has received UCF awards for excellence in research and graduate teaching and has been twice recognized for nationally outstanding research in teacher education by the Association of Teacher Educators. Currently, he works with the Sloan Consortium and the National Learning Infrastructure Initiative on evaluating the nation's distributed learning initiative. Dr. Dziuban was named UCF's first ever Pegasus Professor for extraordinary teaching, research, and service.

Patsy Moskal is Associate Director for the Research Initiative for Teaching Effectiveness at the University of Central Florida (UCF) where she has been a faculty member since 1989. She received an Ed.D. from UCF specializing in Instructional Technology and Research Methods and holds BS and MS degrees in computer science. Since 1996 she has served as the liaison for faculty research of distributed learning at UCF. Patsy specializes in statistics, graphics, and applied data analysis. She has extensive experience in research methods including survey development, interviewing, and conducting focus groups and frequently serves as a consultant to school districts, industry, and government organizations.

Jay Brophy is an Associate Professor of Psychology at the University of Central Florida. Jay studied at Stetson University where he received his BA and earned his Ph.D. in Psychology from Vanderbilt in 1969 
Student Satisfaction with Asynchronous Learning

in Learning Theory and Physiological Psychology. During Jay's 36-year career at UCF, he has been instrumental in bringing innovative technology into the classroom. He has been involved with Course Development and Web Services at UCF since its inception. An early user of WebCT, he has offered courses in traditional, hybrid-reduced seat time, and fully Web-based courses since 1996. During the last five years Jay has been teaching large sections (400+ students) of General and Physiological Psychology with a heavy emphasis on web enhanced instruction. Jay has earned numerous teaching awards, and is currently a Senior Teaching Fellow with the UCF Faculty Center for Teaching and Learning.

Peter Shea is an assistant professor in the department of Educational Theory and Practice with a joint appointment in the College of Computing and Information at the University at Albany, State University of New York. Previously he served as the Director of the SUNY Learning Network, the multiple-award winning, online education system for the State University of New York. Peter has also served as manager of the SUNY Teaching, Learning, and Technology Program and as Project Director in the Multimedia Educational Resource for Learning and Online Teaching (MERLOT), as well as a SUNY representative to the EDUCAUSE National Learning Infrastructure Initiative (NLII-now ELI).

Peter's current research focuses on the student and faculty experience in technology-mediated teaching and learning, most recently on the topics of "teaching presence" and community in asynchronous learning networks. He is the author of many articles and several book chapters on the topic of online learning, coauthor of the book, The Successful Distance Learning Student (Thomson-Wadsworth) and a contributor to the recent book, Learning Together Online, Research on Asynchronous Learning Networks (Erlbaum). He is a co-recipient of several awards including the EDUCAUSE Award for Systemic Progress in Teaching and Learning for the State University of New York, and two Sloan Consortium Awards for Excellence in Faculty Development and Asynchronous Learning Networks Programs. He is a member of the American Educational Research Association and the editorial board for the Journal of Asynchronous Learning Networks. His research has appeared in the Journal of Educational Computing Research, The International Review of Research in Open and Distance Learning, and the Journal of Asynchronous Learning Networks among others.

\section{REFERENCES}

1. Dziuban, C., P. Moskal and L. Futch. Reactive Behavior, Ambivalence, and the Generations: Emerging patterns in student evaluation of blended learning. Blended Learning: Research Perspectives. Needham, MA: Sloan-C, 2007.

2. Postman, N. Technopoly: the Surrender of Culture to Technology. New York: Vintage Books, 1993.

3. Postman, N. Amusing Ourselves to Death: Public Discourse in the Age of Show Business. New York: Penguin, 1985.

4. Dertouzos, M. What Will Be: How the New World of Information will Change Our Lives. New York, New York: Harper Collins, 1997.

5. Kellner, D. Cultural Studies, Identity and Politics Between the Modern and the Postmodern Media Culture. New Fetter Lane, London: Routledge, 1995.

6. Morris, L. Have the devices changed the learner? Innovative Higher Education 31(1): 1-3, 2006.

7. Mitch, L. The People's Encyclopedia. Science 301(5638): 1299, 2003.

8. Korfiatis, N., M. Poulos and G. Bokos. Evaluating authoritative sources using social networks: an insight from Wikipedia. Online Information Review 30(3): 252-262, May 2006.

9. Lanier, J. Digital Maoism: The Hazards of the New Online Collectivism, 2006. http://www.edge.org Brd culture/lanier06/lanier06 index.html.

10. Friedman, T. L. The World is Flat: A Brief History of the Twenty-first Century. New York, NY: Farrar, Straus and Giroux, 2005. 
11. Doctrow, C. On "Digital Maoism: The Hazards of the New Online Collectivism" By Jaron Lanier, 2006. http://www.edge.org/discourse/digital maoism.html.

12. Jones, D. NCHEMS News - March 1996, 1996.

13. Chad, K. and P. Miller. Do Libraries Matter? The Rise of Library 2.0, 2005. http://www.talis.com /downloads/white_papers/DoLibrariesMatter.pdf.

14. Oblinger, D. Integrating Tradition and Technology. Presentation at the Cornell University Computer Policy and Law Program, Ithaca, NY, 2006. http://www.cit.cornell.edu/oit/ucpl/.

15. Skiba, D. The Millennials: Have they arrived at your school of nursing? Nursing Education Perspectives 26(6): 370-371, 2005.

16. Prensky, M. Listen to the Natives. Educational Leadership 63(4): 8-13, Dec 2005/Jan 2006.

17. Wager, J. Support Services for the Net Generation: The Penn State Approach. College \& University 81(1): 3-10, Summer 2005.

18. Dziuban, C. D., P. D. Moskal and J. Hartman. Higher education, blended learning, and the generations: Knowledge is power: No more. In: J. R. Bourne and J. C. Moore (Eds.), Elements of Quality Online Education: Engaging Communities. Needham, MA: Sloan-C, 2005.

19. Abram, S. and J. Luther. Born with the chip: The next generation will profoundly impact both library service and the culture within the profession. Library Journal 129(8): 34, 2004.

20. Howe, N. and W. Strauss. Millennials Rising: The Next Great Generation. New York, NY: Vintage Books, 2000.

21. Prensky, M. Digital Natives, Digital Immigrants. In: F. Yonekura, A Study of Millennial Students and Their Reactive Behavior Patterns in the Online Environment, 17. Dissertation at the University of Central Florida, Department of Educational Studies, 2006.

22. Bisoux, T. Rethinking It. In: F. Yonekura, A Study of Millennial Students and Their Reactive Behavior Patterns in the Online Environment, 20. Dissertation at the University of Central Florida, Department of Educational Studies, 2006.

23. Prensky, M. On the Horizon 9:6, November-December 2001. In: F. Yonekura, A Study of Millennial Students and Their Reactive Behavior Patterns in the Online Environment, 17. Dissertation at the University of Central Florida, Department of Educational Studies, 2006.

24. Brown, J. S. Growing Up Digital. Change 32(2): 10-11, March/April 2000.

25. Frand, J. The Information-Age Mindset: Changes in Students and Implications for Higher Education. EDUCAUSE Review 35(5): 15-24, September/October 2000.

26. Oblinger, D. Boomers, Gen-Xers, and Millennials: Understanding the 'New Students.' EDUCAUSE Review 38(4): July/August 2003.

27. Tenner, E. Searching for Dummies. The New York Times, March 26, 2006. http://www.nytimes.com/2006/03/26/opinion/26tenner.html.

28. Prensky, M. Engage Me or Enrage Me: What Today's Learner's Demand. EDUCAUSE Review 40(5): 60-64, September/October 2005. http://www.educause.edu/ir/library/pdf/erm0553.pdf.

29. Twenge, J. M. Generation Me: Why Today's Young Americans are More Confident, Assertive, Entitled-And More Miserable Than Ever Before. New York, NY: Free Press, 2006.

30. Feldman, K. A. The superior college teacher from the students' view. Research in Higher Education 5: 243-288, 1976.

31. Marsh, H. W. and L. A. Roche. Making students' evaluations of teaching effectiveness effective: The critical issues of validity, bias, and utility. American Psychologist 52(11): 1187-1197, 1997.

32. Dziuban, C. D., M. C. Wang and I. J. Cook. Dr. Fox rocks: Student perceptions of excellent and poor college teaching. Unpublished manuscript, University of Central Florida, 2004.

33. Shea, P., E. Fredericksen, A. Pickett and W. Pelz. Student satisfaction and reported learning in the SUNY Learning Network. In: T. Duffy and J. Kirkley, Learner Centered Theory and Practice in Distance Education. Mahwah, NJ: Lawrence Erlbaum, 2003.

34. Bangert, A. W. Identifying factors underlying the quality of online teaching effectiveness: An exploratory study. Journal of Computing in Higher Education 17(2): 79-99, Spring 2006. 
35. Chickering, A. W. and S. C. Erhmann. Implementing the seven principles: Technology as lever. AAHE Bulletin 49(2): 3-6, 1996.

36. Kuh, G. D. Assessing what really matters to student learning. Change 33(3): 10-19, 2001.

37. Dahl, J. Online services keep Syracuse students satisfied. Distance Education Report: 4-8, November 2005.

38. DiBiase, D. The impact of increasing enrollment on faculty workload and student satisfaction over time. Journal of Asynchronous Learning Networks 8(2): 45-60, 2004.

39. Shea, P. and C. S. Li. A comparative study of "Teaching Presence" and student sense of learning community in online and classroom environments. The Internet and Higher Education 9(3): 175-191, 2006.

40. Shea, P. J., A. M. Pickett and W. E. Pelz. A follow-up investigation of "teaching presence" in the SUNY learning network. Journal of Asynchronous Learning Networks 7(2): 61-80, 2003.

41. Sener, J. and J. Humbert. Student satisfaction with online learning: An expanding universe. Elements of Quality Online Education: Practice and Direction. Needham, MA: Sloan-C, 2003.

42. Swan, K. Building learning communities in online courses: The importance of interaction. Education, Communication, \& Information 2(1): 23-49, 2002.

43. Linn, L., P. Cranton and B. Bridglall. Psychological type and asynchronous written dialogue in adult learning. Teachers College Record 107(8): 1788-1813, 2005.

44. Shea, P., C. Li, K. Swan and A. Pickett. Developing learning community in online asynchronous learning networks. Journal of Asynchronous Learning Networks 9(4): 59-82, 2005.

45. Stein, D. Course Structure: Most important factor in student satisfaction. Distance Education Report 8(3): 4, 2004.

46. Helft, M. Young internet producers, bankrolled, are seeking Act II. New York Times, C1, Monday, September 25, 2006. 